\title{
Estimation of the Global Solar Radiation with the Artificial Neural Networks for the City of Sivas
}

\author{
Cahit Gurlek', Mustafa Sahin ${ }^{2}$ \\ 1Department of Mechanical Engineering, Cumhuriyet University, Sivas, Turkey; cgurlek@cumhuriyet.edu.tr \\ 2Turkish Railway Machines Industry Inc., Sivas, Turkey; mustafasahin@tudemsas.gov.tr
}

\begin{abstract}
In this study, global solar radiation in the city of Sivas was estimated by artificial neural networks (ANNs) using meteorological and geographical data obtained from four different measurement stations. Mean bias error (MBE), root mean square error (RMSE) and $R^{2}$ ranged from $-1.264 \mathrm{MJ} / \mathrm{m}^{2}$ to $0.938 \mathrm{MJ} / \mathrm{m}^{2}, 0.710 \mathrm{MJ} /$ $\mathrm{m}^{2}$ to $1.598 \mathrm{MJ} / \mathrm{m}^{2}$ and 0.984 to 0.994 , respectively. It is believed that ANN models could be used to predict global solar radiation for locations where only the temperature and sunshine duration data are available in the city of Sivas.
\end{abstract}

Keywords: Artificial neural networks, Sivas, Solar radiation, Sunshine duration

\section{INTRODUCTION}

Solar radiation is the most important meteorological parameter for many engineering applications, such as heating, cooling, energy production and storage, agricultural production, transport and building design. However, it is not widely available because of the cost of measuring equipment and its difficult maintenance and calibration [1]. Therefore, other more readily available meteorological data such as sunshine hours, air temperature, cloudiness, relative humidity, precipitation, etc. have been widely used to estimate solar radiation by means of several prediction models [2-13].

Artificial neural networks (ANNs) based solar radiation prediction models have been developed by various researchers for different regions in Turkey [14-24]. Previous studies have shown that ANN prediction models estimate solar radiation more accurately than other linear, nonlinear and fuzzy logic models [25].

In this study, the ANN method was used for estimating the monthly mean daily global solar radiation of Sivas City using meteorological data of four different measurement stations, namely Divriği, Gemerek, Kangal and Sivas City Center. Sivas is situated in the central part of Turkey, geographically located between east longitudes $35^{\circ} 50^{\prime}$ to $38^{\circ}$ $14^{\prime}$ and north latitudes $38^{\circ} 32^{\prime}$ to $40^{\circ} 16^{\prime}$. It has a continental climate with cold and snowy winters and hot and dry summers. Its long term annual mean temperature, mean minimum and maximum temperatures and mean sunshine duration for the years $1926-2016$ are $8.9^{\circ} \mathrm{C}, 2.8^{\circ} \mathrm{C}, 15.3^{\circ} \mathrm{C}$ and $80.5 \mathrm{~h}$, respectively [26].

\section{MATERIAL AND METHOD}

Artificial neural networks (ANNs) are information processing structures that are inspired by biological nervous systems, such as the human brain. Typically, an ANN consists of three main layers, each of which has a number of interconnected parallel processing units, called neurons (shortly nodes). These are the input layer, the output layer, and between them the hidden layers that can consist of one or more layers. ANNs learn the relation between input and output variables by examining (training) the previously recorded data. Basically, a neuron takes input from incoming connections, combines the input, performs usually a non-linear operation and outputs the final results [27, 28].

In this study, a feed-forward backpropagation (FFBP) ANN model was used for estimating the solar radiation of Sivas City. The ANN architecture used in this study is schematically presented in Figure 1. It had three layers: the input layer, the hidden layer with 6 neurons and the output layer. The meteorological data obtained from the Turkish State Meteorological Service for the years 1986-2000 (2010-2016 for Divriği) were used to perform ANN modeling. A total of six geographical and meteorological variables, month, latitude, longitude, altitude, average temperature and sunshine duration were used in the input layer of the network. The output parameter was the solar radiation. Hyperbolic tangent and sigmoid transfer functions were used in the hidden and output layers, respectively. The Levenberg-Marquardt al- 
gorithm was chosen as the learning algorithm.

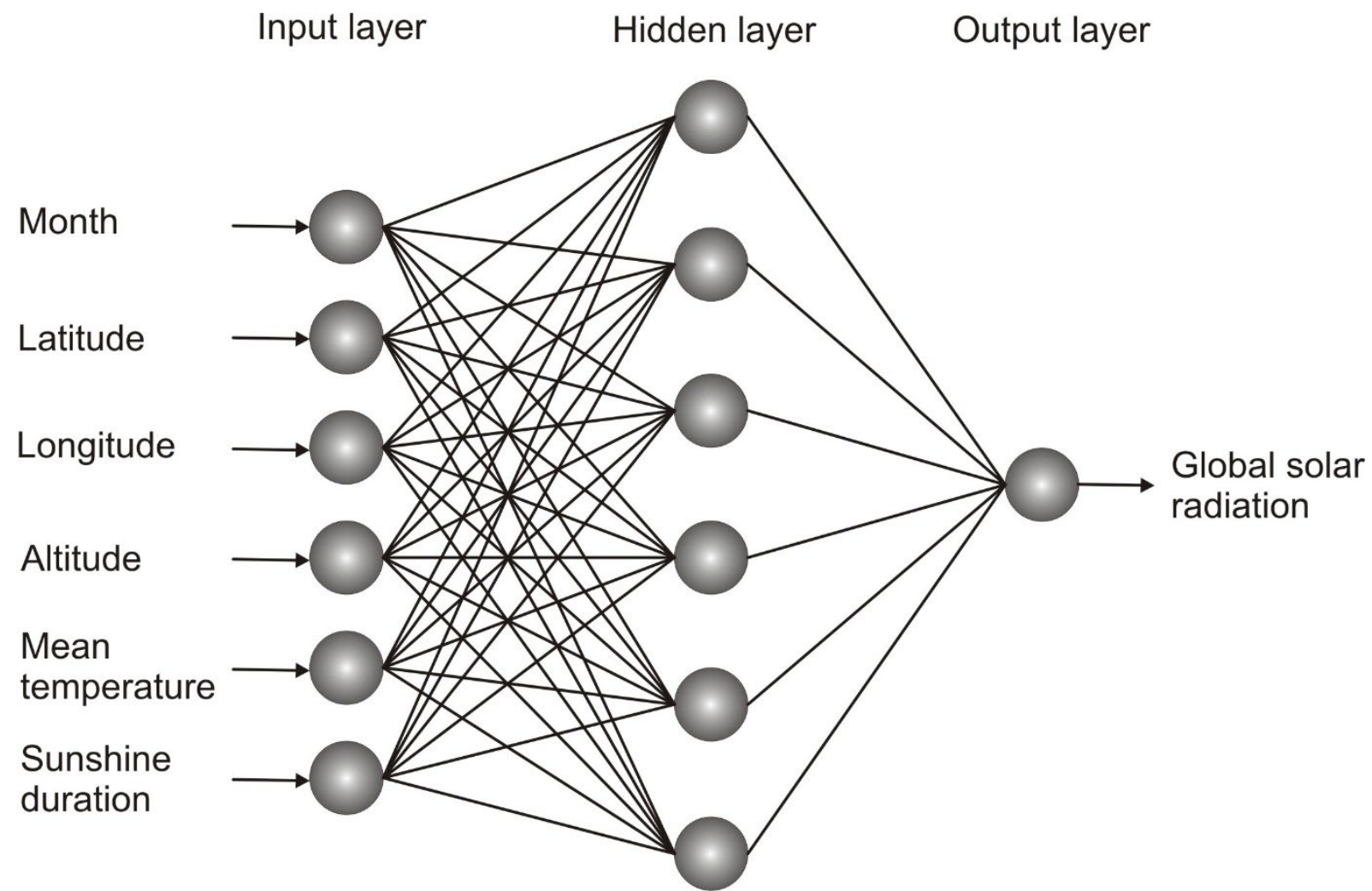

Figure 1. ANN architecture

The performance of the ANN model for each measurement station was validated by mean bias error (MBE), root mean square error (RMSE) and R-squared statistical test methods given by the formulas below. Low values of MBE are desired. Ideally, a zero value should be obtained. A positive and a negative value of MBE indicate overestimation and underestimation, respectively. RMSE is a measure of the deviation between the predicted and measured values. It is always positive and the ideal value is zero. The smaller the RMSE value, the better the model performance. The R-squared coefficient is the measure of goodness-of-fit between the measured and predicted data. As the value approaches 1 , the accuracy of the model increases.

$$
\begin{aligned}
& M B E=\frac{\sum\left(H_{\text {pred }}-H_{\text {meas }}\right)}{n} \\
& R M S E=\sqrt{\frac{\sum\left(H_{\text {pred }}-H_{\text {meas }}\right)^{2}}{n}} \\
& R^{2}=\left[\frac{\sum\left(H_{\text {pred }}-\overline{H_{\text {pred }}}\right)\left(H_{\text {meas }}-\overline{H_{\text {meas }}}\right)}{\sqrt{\sum\left(H_{\text {pred }}-\overline{H_{\text {pred }}}\right)^{2} \sum\left(H_{\text {meas }}-\overline{H_{\text {meas }}}\right)^{2}}}\right]^{2}
\end{aligned}
$$

\section{RESULTS AND DISCUSSION}

In this study, $70 \%$ of the data was used for training and the remaining $30 \%$ for testing. Training and testing of the network continued until there was no improvement in the output. For each measurement station, the measured global solar radiation data in the year 2000 (2016 for Divriği) was used to compare with the predicted results. Figure 2 compares the measured and predicted monthly mean daily global solar radiation values for four stations. It can be seen that the predicted values are in good agreement with the measured data.

Monthly distribution of measured and predicted solar radiation values are given in Figure 3. In general, again, the predicted values obtained from the ANN model are in good agreement with the measurement data for all measurement stations. However, starting from March, the model showed overestimation of solar radiation for Kangal, while it tended to underestimate the values of the Sivas City Center. 
Table 1 presents the mean bias error (MBE), root mean square error (RMSE) and R-squared statistical test results for the measurement stations. The MBE values ranged from $-1,264 \mathrm{MJ} / \mathrm{m}^{2}$ to $0.938 \mathrm{MJ} / \mathrm{m}^{2}$. The lowest MBE value was 0.055 obtained for the measurement station Gemerek. The RMSE values varied from $0.710 \mathrm{MJ} / \mathrm{m}^{2}$ to $1.598 \mathrm{MJ} / \mathrm{m}^{2}$ obtained from the Divriği and Sivas City Center, respectively. The R-square values varied from the highest of 0.994 for Divriği to the lowest of 0.984 for Kangal.

\section{Divriği}
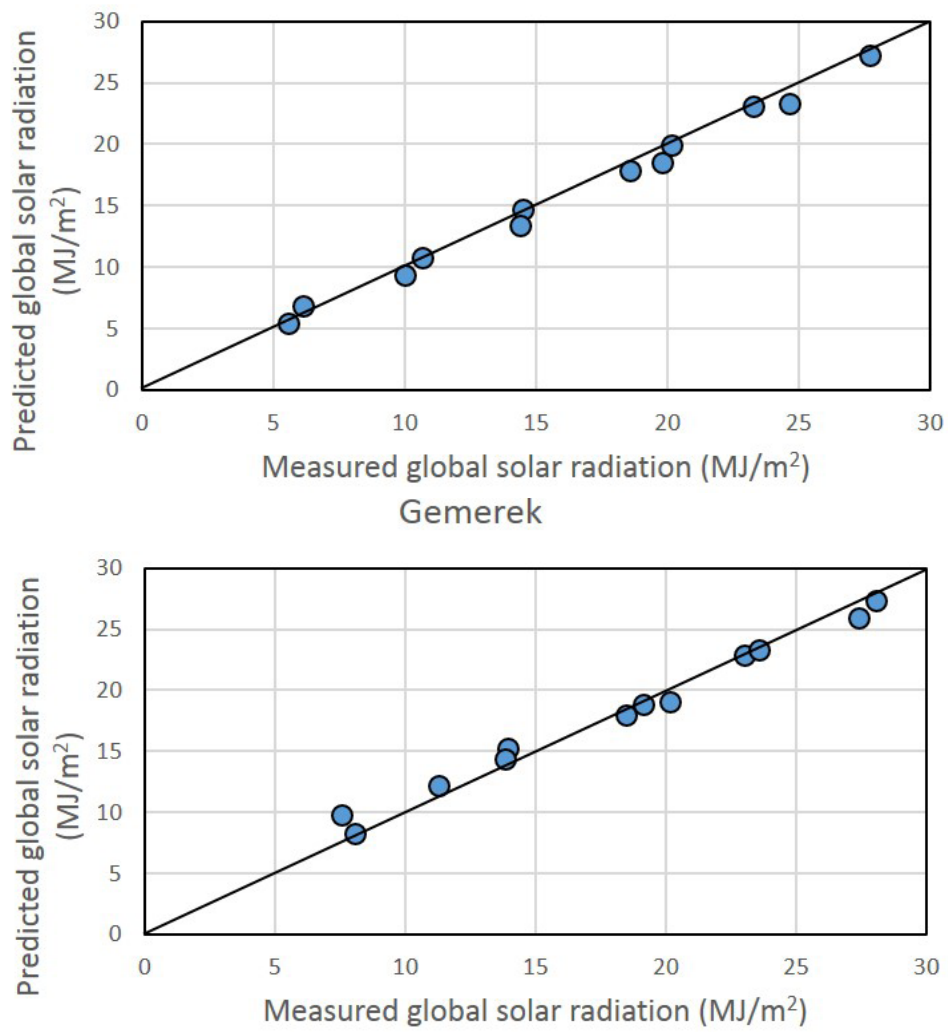

Kangal
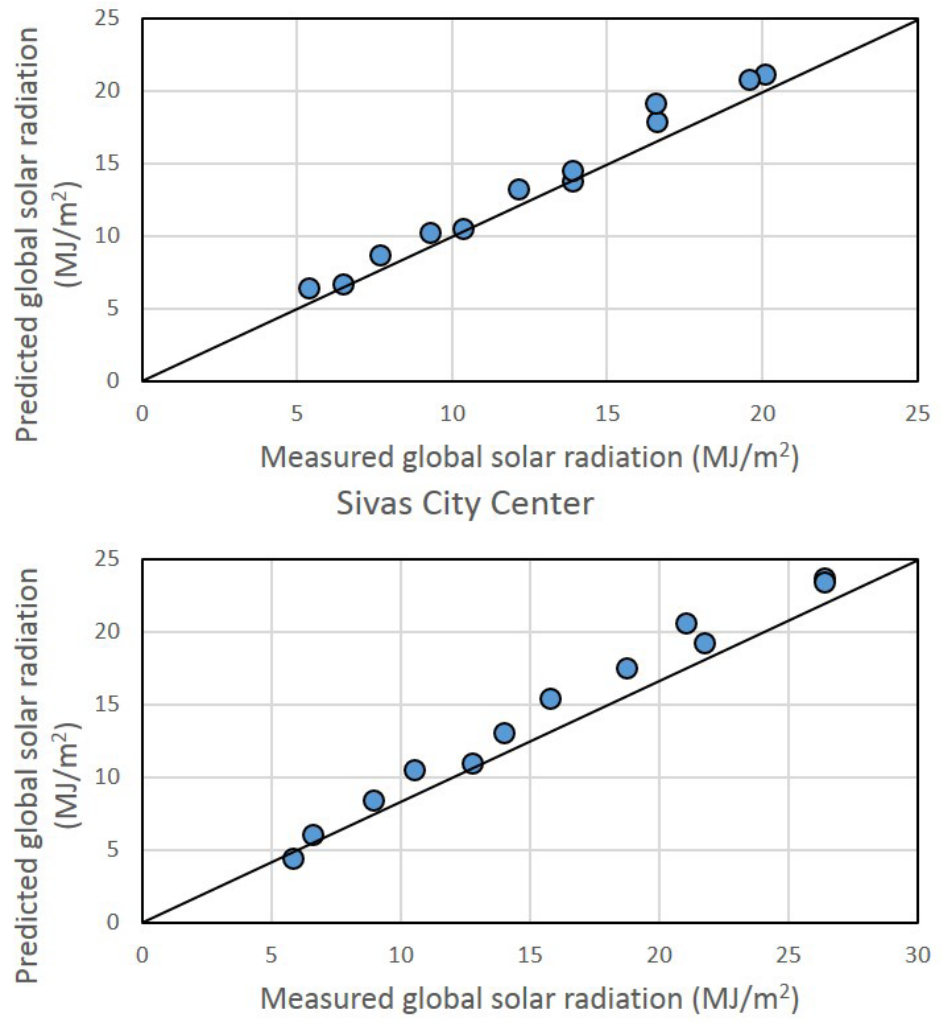

Figure 2. Comparison of measured and predicted global solar radiation 

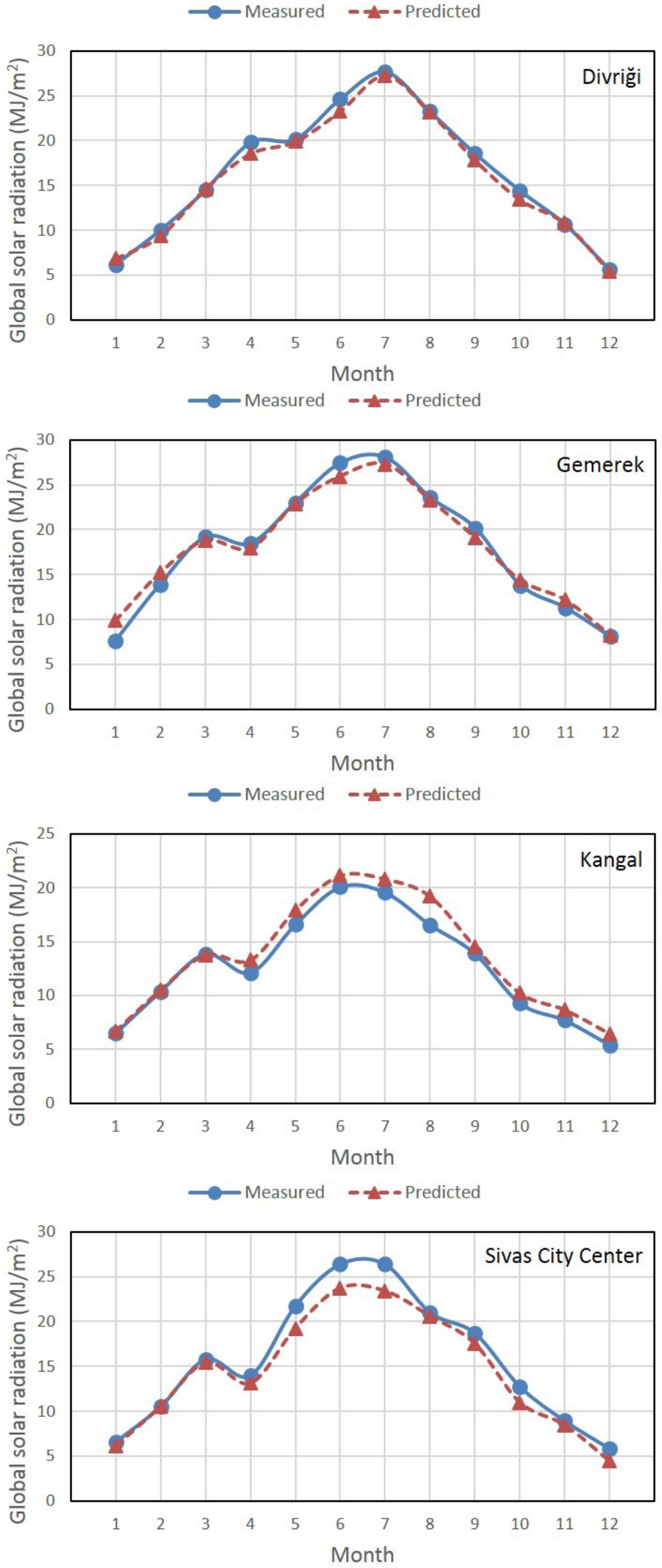

Figure 3. Monthly distribution of measured and predicted global solar radiation 
Table 1. Statistical test results

\begin{tabular}{|c|c|c|c|}
\hline Measurement Station & MBE $\left(\mathrm{MJ} / \mathrm{m}^{2}\right)$ & RMSE $\left(\mathrm{MJ} / \mathrm{m}^{2}\right)$ & R-square \\
\hline Divriği & -0.400 & 0.710 & 0.994 \\
\hline Gemerek & 0.055 & 1.023 & 0.990 \\
\hline Kangal & 0.938 & 1.158 & 0.984 \\
\hline Sivas City Center & -1.264 & 1.598 & 0.987 \\
\hline
\end{tabular}

\section{CONCLUSION}

In this study, global solar radiation values of the four measurement stations in the Sivas City were estimated using artificial neural network (ANN) method. The predicted results are in good agreement with the measurement data for all stations. It is concluded that ANN models could be used to estimate global solar radiation for the regions where only measured temperature and sunshine duration data are available in Sivas City.

\section{ACKNOWLEDGMENTS}

This study was supported by Cumhuriyet University Scientific Research Projects Coordination Unit (Project No. M-688). We would like to thank the Turkish State Meteorological Service for providing meteorological data. We thank Assoc. Prof. Dr. Serkan Akkoyun for his contributions and friendship.

\section{REFERENCES}

[1] Hunt L. A., Kuchar L. and Swanton C. J., (1998) "Estimation of solar radiation for use in crop modelling", Agr. Forest Meteorol., vol.91, pp.293-300

[2] Angstrom A., (1924) "Solar and Terrestrial Radiation Report to the International Commission for Solar Research on Actinometric Investigations of Solar and Atmospheric Radiation", Q. J. R. Meteorol. Soc., vol.50, pp.121-126

[3] Rietveld M. R., (1978) "A new Method for Estimating the Regression Coefficients in the Formula Relating Solar Radiation to Sunshine", Agric. Meteorol., vol.19, pp.243-252

[4] Hargreaves G. H. and Samani Z. A., (1982), "Estimating Potential Evapotranspiration”, J. Irrigat Drainage Div. Eng., vol.8, pp.223-230

[5] Akinoglu B. G. and Ecevit A., (1990) "Construction of a Quadratic Model Using Modified Angstrom Coefficients to Estimate Global Solar Radiation", Sol. Energy, vol.45, pp.85-92

[6] Alnaser W. E., (1993) "New Model to Estimate the Solar Global Irradiation Using Astronomical and Meteorological Parameters", Renewable Energy, vol.3, pp.175-177

[7] Trabea A. A. and Shaltout M. A. M., (2000) "Correlation of Global Solar-Radiation with Meteorological Parameters over Egypt", Renewable Energy, vol.21, pp.297-308

[8] Almoroks J. and Hontoria C., (2004) "Global Solar Radiation Estimation Using Sunshine Duration in Spain", Energy Conversion and Management, vol.45, pp.1529-1535

[9] Kumar R. and Umanand L., (2005) "Estimation of Global Radiation Using Clearness Index Model for Sizing Photovoltaic System", Renewable Energy, vol.30, pp.2221-2233

[10] Fletcher A. L. and Moot D. J., (2007) Estimating Daily Solar Radiation in New Zealand Using Air Temperatures", N. Z. J. Crop Hortic. Sci., vol.35, pp.147-157

[11] Bakirci K., (2009) "Correlations for Estimation of Daily Global Solar Radiation with Hours of Bright Sunshine in Turkey", Energy, vol.34, pp.485-501

[12] Koussa M., Malek A. and Haddadi M., (2009) "Statistical Comparison of Monthly Mean Hourly and Daily Diffuse and Global Solar Irradiation Models and a Simulink Program Development for Various Algerian Climates", Energy Convers. Manage., vol.50, pp.1227-1235

[13] Omondi A. and Ongoma V., (2015) "Estimation of Mean Monthly Global Solar Radiation Using Sunshine Hours for Nairobi City, Kenya", J. Renewable and Sustainable Energy, vol.7.

[14] Sözen A., Arcaklioğlu E., Özalp M., and Kanit, E. G., (2004) "Use of artificial neural networks for Mapping of Solar Potential in Turkey". Applied Energy, vol.77, pp.273-86

[15] Sözen A., Arcaklioğlu E. and Özalp M., (2004) "Estimation of Solar Potential in Turkey by Artificial Neural Networks Using Meteorological and Geographical Data" Energy Conversion and Management, vol.45, pp.3033-52

[16] Koca A., Oztop H. F, Varol Y., and Koca G.O., (2011) "Estimation Of Solar Radiation Using Artificial Neural Networks with Different Input Parameters for Mediterranean Region of Anatoliain Turkey", Expert Systems with Applications, vol.38, pp.8756-62

[17] Şenkal O. and Kuleli T., (2009) "Estimation of Solar Radiation over Turkey Using Artificial Neural Network and Satellite Data", Applied Energy, vol.86, pp.1222-8

[18] Şenkal O., (2010) "Modeling of Solar Radiation Using Remote Sensing and Artificial Neural Network in Turkey", Energy, vol.35, pp.4795-801 
[19] Sözen A. and Arcaklioğlu E., (2005) "Solar Potential in Turkey", Applied Energy, vol.80, pp.35-45

[20] Yildiz B. Y, Şahin M., Şenkal O., Pestemalci and Emrahoğlu N. A., (2013) "Comparison of two Solar Radiation Models Using Artificial Neural Networks and Remote Sensing in Turkey" Energy Sources, Part A, vol.35, pp.209-17

[21] Şenkal O., Şahin M and Pestemalci V., (2010) "The Estimation of Solar Radiation for Different Time Periods. Energy Sources", Part A, vol.32, pp.1176-84

[22] Şen Z., Öztopal A. and Şahin A. D. (2004) "Solar Irradiation Estimation from Sunshine Duration by Geno-Fuzzy Partial Approach. Energy Sources", vol.26, pp.377-86

[23] Şahin A. D. and Şen Z., (1998) "Statistical Analysis of the Angström Formula Coefficients and Application for Turkey", Solar Energy, vol.62, pp.29-38

[24] Celik A. N. and Muneer T., (2013) "Neural Network Based Method for Conversion of Solar Radiation Data", Energy Conversion and Management, vol.67, pp.117-24

[25] Yadav A. K. and Chandel S.S., (2013) “Solar Radiation Prediction Using Artificial Neural Network Techniques a Review”, Renewable and Sustainable Energy Reviews, vol.33, pp.771-781

[26] https://www.mgm.gov.tr/veridegerlendirme/il-ve-ilceler-istatistik.aspx?k=undefined\&m=SIVAS, 2017

[27] Lam C. J., Wan K. K. W. and Yang L., (2008) “Solar Radiation Modelling Using Anns for Different Climates in China”, vol.49, pp.1080-1090

[28] Görler O. and Akkoyun S., (2017) "Artificial Neural Networks Can be Used as Alternative Method to Estimate Loss Tooth Root Sizes for Prediction of Dental Implants", C.U. Faculty of Science Science Journal, vol.38, pp.1300-1949 